\title{
Prevalence and Distribution of Plague And TUlaremia IN SMALl MAMMALS OF GRAND Teton National Park
}

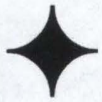 \\ ASAF DAGAN $\downarrow$ COLIN M. GILLIN $\uparrow$ TUFTS UNIVERSITY SCHOOL OF VETERINARY MEDICINE \\ NORTH GRAFTON $\downarrow$ MA \\ KIRA MARCINIAK $\uparrow$ HARVARD MEDICAL SCHOOL \\ BOSTON $\uparrow \mathrm{MA}$
}

\section{INTRODUCTION}

Sylvatic plague (Yersinia pestis) and tularemia (Francisella tularensis) are infectious bacterial diseases that can be transmitted from wild mammals to humans by insects or through direct contact. Although cases of plague and tularemia have been reported in the southwest, a comprehensive understanding of the prevalence, distribution and dynamics of these diseases is lacking.

During the months of June and July 2000 we sampled small mammals in Grand Teton National Park (GTNP) for antibodies of these zoonotic diseases. This survey was conducted in conjunction with a large scale population dynamics study, lead by Dr. Brian Miller, Denver Zoological society, and Dr. Hank Harlow, Department of Zoology and Physiology, University of Wyoming.

A published survey of plague and tularemia has not been conducted in GTNP. In 1996, Dr. Fredrick Jannett looked for plague in the genus Microtus and found low incidence $(<1 \%)$. Sample sizes and analysis methods were not provided in the report (Jannett 1996). However, he expected disease prevalence to be distributed randomly among habitat types but to be higher in populated versus unpopulated areas in the park.
GTNP is a popular National Park that receives over 2 million human visitors annually. Within the park boundaries a high level of interaction between humans and wildlife exists near visitor centers and roadside vehicle pullouts, creating an increased risk of exposure to zoonotic diseases (Kumar et al. 1997; Aguirre and Starkey (1994). Therefore, we felt that this type of survey might prove invaluable to park managers.

\section{METHODS}

Except for one site, discussed below, all the animals sampled were captured as part of a population study conducted by Dr. Miller and Dr. Harlow (see related report in this issue). Capture methods are discussed in detail in their report. We sampled captured animals only on the last day of each trapping site, in order to prevent possible bias in the population study as a result of possible injuries or mortalities during blood sampling. The following sites were screened: Lozier Hill, Christian Pond, Pacific Creek, and Grand View (for specific locations see Dr. Harlow and Dr. Miller's report).

One site, however, was screened independently. This was also the only populated habitat surveyed at the AMK ranch near Jackson Lake. We used $22.5 \mathrm{~cm}$ long and 7.5 by $7.5 \mathrm{~cm}$ wide 
Table 1. Site locations and number of indiciduals of each species tested. Names in parentesis relate to different locations on the same area.

\begin{tabular}{|c|c|c|c|c|c|c|}
\hline Site & $\begin{array}{l}\text { Peromyscus } \\
\text { maniculatus }\end{array}$ & $\begin{array}{l}\text { Microtus } \\
\text { pennsylvanicus }\end{array}$ & Citellus armatus & Tamias minimus & $\begin{array}{l}\text { Zapus } \\
\text { princeps }\end{array}$ & Clethrionomys gapperi \\
\hline AMK ranch & 42 & 4 & 13 & 3 & 5 & \\
\hline Lozier Hill & 4 & & & & & \\
\hline Christian Pond & & 13 & & & & \\
\hline Pacific Creek & $\begin{array}{l}14 \text { (sage 1) } \\
7 \text { (sage 2) }\end{array}$ & 1 (sage 1 ) & & 3 (pine) & & 2 (pine) \\
\hline Grand View & & 17 & & & & \\
\hline
\end{tabular}

folding Sherman traps and the same bait as was used in all sites. Traps were opened late in the day and closed after checking the next morning. All the captured animals at the AMK ranch were sampled. They were later released away from the buildings.

Captured animals were placed in a transparent anesthesia box containing cotton balls soaked with Isoflorane (IsoFlo, 5260-04-03, Abbott Laboratories, N orth Chicago, IL 60004). Blood w as collected from the anesthetized animals via the retroorbital sinus using heparanized microhematocrit tubes (J-543, Am-Heparanized, iso 12772, Jorgensen Laboratories inc., Loveland, CO 80538). The tubes were kept in an icebox until returning to the lab at the research station later each morning. The animals were allowed to recover from the anesthesia and then released near their capture site.

Microhematocrit tubes were centrifuged to separate cells from plasma. The amount of recovered plasma was measured (Precision pipette: Eppendorf series 2100 pipette 20-200. $\square$ L), Cat. No. 2247205-4), and then diluted by a 1:8 ratio with saline (normal saline solution, NDC 50989-368-16, Vedco Inc., S t. Joseph, MO 64504). The diluted samples were stored in a freezer in Eppendorf Tubes (Safe-Lock $2.0 \mathrm{~mL}$, PP/US Pat. No 4,713,219. Cat. No.: 2236335-2). The samples were shipped overnight to Wyoming Game and Fish Wildlife Disease Laboratory in Laramie, Wyoming, where they were analyzed for plague and tularemia using CDC-ELISA and PHA/PHI titers.

\section{RESULTS}

A total of 128 animals were sampled, (Table 1) according to the following breakdown: 67 deer mice (Peromyscus maniculatus), 35 meadow voles
(Microtus pennsylvanicus), 13 Uinta ground squirrels (Citellus armatus), 6 least chipmunks (Tamias minimus), 5 western jumping mice (Zapus princeps), and 2 boreal redback voles (Clethrionomys gapperi).

As expected, different habitats support different species. Therefore, there was a significant variation in the type of animals sampled at the various sites.

All the samples from all the sites tested negative for both plague and tularemia.

\section{DISCUSSION}

The all negative result was unexpected, especially in light of Jannett's study. Variability in the bleeding, shipment or screening protocols were believed to be reasonable and not expected to affect the results. However, several other reasons may explain this outcome.

First, sample size may have affected the results. Although we had no specific previous data, we assumed that deer mice, known to be endemically infected with plague, will show $2-4 \%$ prevalence. Runnning the Poisson formula on the 67 deer mice samples collected yielded a border line result, too close to the $5 \%$ cut-off required for becoming statistically significant [For 2.0: $\operatorname{Pr}(\mathrm{X}=0)=\mathrm{e}^{-2} 2^{0} \%$ $2 !=0.135=13.5 \%$; For $2.7(\sim 4 \%):(0.0083 \times 0.7)+$ $(0.135 \times 0.3)=4.63 \%$ ]. Hence, we $c$ annot rule out low sample size as the reason for the negative result, yet we cannot positively and convincingly claim that this is the sole explanation.

The ELISA protocol is a sensitive tool for detecting antibodies. Nevertheless, the titer of antibodies in these animals may be too low to be 
detected even by ELISA. The amount of plasma that we can safely collect from small mammals is limited by the size of the animal and its total blood volume if we want to prevent hypovolemic shock. Many of the samples (68) had a volume of $200-240 \mu \mathrm{L}$ after dilution. A total of 95 samples (74\% of the total) were $240 \mu \mathrm{L}$ or smaller. Whether bigger samples are required in order to prevent false negatives is yet to be decided.

Another possible explanation is a change in the host population size. This was ruled out due to a finding of no significant difference in the population size this year as compared to last year (B. Miller, personal comm.).

However, another environmental factor might have bearing on the issue. The spring of 2000 was hotter and drier than the two previous corresponding seasons (Table 2). The months of April, May and June 2000 saw less total precipitaion and higher average temprature than the same months during 1998 and 1999:

\begin{tabular}{|c|c|c|c|c|c|c|}
\hline & \multicolumn{3}{|c|}{ Average Temp (F) } & \multicolumn{3}{|c|}{ Total Precipitation } \\
\hline & April & May & June & April & May & June \\
\hline 1998 & 35.3 & 45.2 & 47.8 & 2.05 & 3.3 & 3.3 \\
\hline 1999 & 32.8 & 41.5 & 50.9 & 2 & 1.9 & 2.51 \\
\hline 2000 & 38.4 & 45.5 & 53.5 & 1.29 & 2.74 & 1.25 \\
\hline
\end{tabular}

Table 2. Average monthly temperatures and predipitation during these months over three years in GTNP.

Perhaps this climate change created an environmental stress that induced a behavioural change, which in turn influenced probabilities of infection, or a change in the vector population (insects), that would again decrease the probability of infection.

It is also safe to consider the possibility that the dynamics of these diseases are more complex than what is usually assumed. Arguably, instead of a simple constant endemic situation, the bactrium population fluctuates. It is worth noting at this point, that a different study at the Shirley-Basin area, conducted by Wyoming Game and Fish Department also found zero prevelence of plague in Peromyscus maniculatus this year (unpublished), although in the past ten years they always found $2-4 \%$ prevalence.

\section{CONCLUSIONS}

Our survey of the prevalence of plague and tularemia in small mammals at GTNP yielded negative results. Although this might be attributable to a relatively small sample size, we cannot, at this point, rule out more complex explanations.

We believe that a follow-up survey would gain a more comprehensive picture of the zoonotic risk at GTNP and for possible ilucidation of the dynamics of these diseases.

\section{ACKNOWLEDGEMENTS}

Center for Conservation Medicine, Tufts University. Brian Miller, $\mathrm{PhD}$, Denver Zoological Society. Hank Harlow, $\mathrm{PhD}$, Department of Zoology and Physiology, University of Wyoming.

\section{$\downarrow \quad$ Liturature Cited}

Aguirre A A., Starkey E E. (1994). Wildlife disease in U.S. National Parks: Historical and coevolutionary perspectives. Conservation Biology. 8(3), 654-661.

Jannett J F, 1996. Metapopulations and feeding selectivity of Montane and Long-tailed Voles, and Hantavirus and Plague in the Jackson Hole small mammal community, $20^{\text {th }}$ annual report, U. of WY - National Park Research Center.

Kumar K., Jamil-Ur-Rahman S., Sharma S K., Gill K S., Katyal R., Kaur R., Thomas T G., Barua K. (1997). Entomological and rodent surveillance in plague-suspected areas during September 1994 and thereafter. Japanese Journal of Medical Science \& Biology. 50(3), 97-111. 